\title{
HUBUNGAN KOMPETENSI PEDAGOGIK MAHASISWA PPL DENGAN HASIL BELAJAR SISWA PADA MATERI GETARAN DAN GELOMBANG KELAS VIII DI SMP NEGERI 10 KOTA KUPANG TAHUN AJARAN 2018/2019
}

\section{THE RELATIONSHIP OF PPL STUDENTS PEDAGOGICAL COMPETENCIES TO THE LEARNING OUTCOMES IN VIBRATION AND WAVE MATERIAL IN CLASS VIII IN PUBLIC JUNIOR HIGH SCHOOL 10 KUPANG CITY ACADEMIC YEAR 2018/2019}

\author{
Junisari Korlianda Yonarti Adoe ${ }^{1)}$, Agus Maramba Meha ${ }^{1)^{\star}}$, Yonatan Foeh ${ }^{2)}$ \\ ${ }^{1}$ Program Studi Pendidikan Biologi, Fakultas Keguruan dan IImu Pendidikan, Universitas Kristen \\ Artha Wacana, Kupang-NTT \\ ${ }^{2}$ Institut Agama Kristen Negeri Kupang \\ "Corresponding author: us.meha17@gmail.com
}

\begin{abstract}
ABSTRAK
Pembelajaran di dalam kelas yang dilakukan oleh mahasiswa PPL ditemukan banyak siswa yang kurang paham dengan materi yang diajarkan, hal ini terjadi karena banyak mahasiswa PPL yang belum memiliki kompetensi pedagogik yang baik. Penelitian ini dilakukan untuk mengetahui hubungan kompetensi pedagogik mahasiswa PPL dengan hasil belajar siswa. Populasi dalam penelitian ini adalah siswa kelas VIII SMPN 10 Kupang, sedangkan sampel adalah siswa yang berjumlah 21 orang. Pengumpulan data dilakukan dengan tes hasil belajar yang diberikan kepada siswa untuk menilai hasil belajar siswa, dan angket diberikan kepada siswa untuk mengumpulkan kemampuan mahasiswa PPL saat mengajar. Data hasil belajar dan data angket dianalisis menggunakan uji korelasi produk momen, dengan bantuan SPSS versi 18. Berdasarkan hasil uji normalitas diperoleh nilai signifikan $0,954>0,05$, uji linearitas $0,506>0,05$ serta hasil uji hipotesis diperoleh taraf signifikan $0,110>0,05$. Hal ini menunjukan bahwa tidak terdapat hubungan antara kompetensi pedagogik mahasiswa PPL dengan hasil belajar siswa, R Hitung 0,359 menunjukan bahwa korelasi antara kompetensi pedagogik dengan hasil belajar siswa sangat lemah. Hasil belajar siswa yang memuaskan tidak bergantung pada kompetensi pedagogik mahasiswa PPL tetapi karena adanya faktor lain dalam penelitian ini, yaitu faktor internal siswa seperti kesiapan belajar dari siswa, psikologi, dan kematangan siswa. Sumbangan faktor internal dalam penelitian ini sebesar $88 \%$, hal ini menunjukan bahwa hasil belajar tidak bergantung dari kompetensi pedagogik guru melainkan dari siswa itu sendiri.
\end{abstract}

Kata Kunci : Kompetensi Pedagogik, Hasil Belajar, Mahasiswa PPL

\section{ABSTRAC}

In the classroom learning carried out by PPL students, it was found that many students did not understand the material being taught, this happened because many PPL students did not have good pedagogical competence. This research was conducted to determine the relationship between PPL student pedagogical competence and student learning outcomes. The population in this study were students of class VIII SMPN 10 Kupang, while the sample was 21 students. The data was collected by means of a learning outcome test given to students to assess student learning outcomes, and a questionnaire given to students to collect the PPL students' abilities while teaching. Learning outcome data and questionnaire data were analyzed using the moment product correlation test, with the help of SPSS version 18. Based on the results of the normality test, a significant value of 0.954>0.05 was obtained, the linearity test was $0.506>0.05$ and the results of the hypothesis test were obtained at a significant level of $0.110>0.05$. This shows that there is no relationship between the pedagogic competence of PPL students and student learning outcomes, $R$ count 0.359 shows that the correlation between pedagogic competence and student learning outcomes is very weak. Satisfactory student learning outcomes do not depend on the pedagogical competence of PPL students but because of other factors in this study, namely internal student factors such as student learning readiness, psychology, and student maturity. The contribution of internal factors in this study was $88 \%$, this shows that learning outcomes do not depend on the pedagogical competence of the teacher but from the students themselves.

Keyword : Pedagogic competence, Learning outcomes, PPL Student 


\section{PENDAHULUAN}

Biologi adalah ilmu yang mengkaji tentang makhluk hidup, lingkungan dan hubungan antara keduanya. Materi biologi tidak hanya berkaitan dengan fakta-fakta ilmiah tentang fenomena alam yang konkret, tetapi juga berkaitan dengan hal-hal yang abstrak seperti prosesproses metabolisme kimiawi dalam tubuh, sistem hormonal, sistem koordinasi, dan lain-lain. Luasnya kajian dalam ilmu biologi membuat sifat objek materi yang dipelajari sangat beragam, baik ditinjau dari ukurannya, keterjangkuannya, keamanannya, bahasa-bahasa Latin, dan sebagainya. Hal tersebut menyebabkan pembelajaran biologi harus dirancang sebaik mungkin menggunakan berbagai alat dukung seperti penggunaan media belajar, sarana laboratorium, dan lain-lain sehingga siswa tidak hanya dituntut untuk menghafal berbagai konsep biologi tetapi siswa mampu untuk berpikir secara kritis, logis, analitis, dan pada akhirnya siswa memiliki hasil belajar yang baik (Rustaman, 2010).

Hasil belajar merupakan salah satu indikator keberhasilan proses pembelajaran. Hasil belajar adalah sebuah nilai akhir yang diberikan dari seorang guru terhadap siswa sesuai dengan kemampuan selama proses belajar berlangsung. Menurut Abdurrahman (2003), hasil belajar adalah kemampuan yang diperoleh anak setelah melalui kegiatan belajar, yaitu suatu proses dari seorang yang berusaha untuk memperoleh suatu bentuk perubahan perilaku yang menetap. Hasil belajar siswa dalam pembelajaran dapat dibagi kedalam tiga ranah, salah satunya adalah ranah kognitif. Utari (2010) menjelaskan bahwa ranah kognitif berisi perilaku yang menekankan aspek intelektual, seperti pengetahuan dan keterampilan berpikir. Ranah kognitif mengurutkan keahlian berpikir sesuai dengan tujuan yang diharapkan. Proses berpikir menggambarkan tahap berpikir yang harus dikuasai oleh siswa agar mampu mengaplikasikan teori ke dalam perbuatan. Ranah kognitif ini terdiri atas enam level, yaitu level remembering (mengingat), understanding (memahami), applying (menerapkan), analyzing (menganalisis, mengurai), evaluating (menilai) dan creating (mencipta). Pentingnya hasil belajar kognitif siswa sebagai salah satu indikator proses pembelajaran menyebabkan hasil belajar tersebut harus diberdayakan secara sengaja dalam pembelajaran. Upaya pemberdayaan dapat dilakukan dengan cara mengoptimalkan berbagai faktor yang menentukan kualitas hasil belajar termasuk mengoptimalkan kualitas guru. Menurut Slameto (2010) faktor-faktor yang dapat mempengaruhi prestasi belajar yaitu antara lain: faktor jasmaniah (kesehatan), faktor psikologis, perhatian siswa, minat, bakat, motif, kematangan, kesiapan.

Guru dalam tugas keprofesionalannya harus memiliki kompetensi. Menurut Usman (2005), kompetensi adalah suatu hal yang menggambarkan kualifikasi atau kemampuan seseorang baik secara kualitatif maupun kuantitatif. Hal tersebut sejalan dengan Undang-Undang Republik Indonesia nomor 14 tahun 2005 yang mengatakan bahwa kompetensi guru adalah seperangkat pengetahuan, keterampilan, dan perilaku yang harus dimiliki dan dihayati oleh guru atau dosen dalam melaksanakan tugas keprofesionalannya. Undang-Undang Guru dan Dosen tahun 2005 Republik Indonesia pasal 1 ayat 10, guru memiliki empat kompetensi, salah satunya adalah kompetensi pedagogik, dimana kompetensi ini yang menentukan keberhasilan hasil belajar siswa

Menurut Mulyasa (2008) kompetensi pedagogik guru adalah kemampuan mengelola pembelajaran peserta didik yang meliputi pemahaman terhadap peserta didik, perancangan dan pelaksanaan pembelajaran, evaluasi hasil belajar dan pengembangan peserta didik untuk mengaktualisasikan berbagai potensi yang dimilikinya.

Indikator kompetensi pedagogik guru meliputi kemampuan mengelola pembelajaran, pemahaman terhadap peserta didik, pembangunan kurikulum/silabus, perancangan pembelajaran, pelaksanaan pembelajaran yang mendidik dan dialogis, serta pemanfaatan teknologi pembelajaran. Kompetensi pedagogik memiliki pengaruh terhadap hasil belajar siswa hal tersebut terbukti berdasarkan penelitian yang dilakukan oleh Irawan (2007) dalam penelitiannya menujukan bahwa ada hubungan positif antara persepsi terhadap kompetensi guru dengan motivasi berprestasi siswa. Selanjutnya Annisa (2005) dalam penelitiannya membuktikan bahwa terdapat hubungan yang positif antara persepsi tentang kompetensi profesional guru 
matematika dengan motivasi belajar matematika pada siswa kelas 1 SMA Negeri Medan. Fakta yang terungkap dari penelitian terdahulu tersebut menunjukkan bahwa upaya pemberdayaan kompetensi pedagogik akan sangat menentukan kualitas hasil belajar kognitif siswa.

Mahasiswa calon guru juga dituntut untuk memiliki kompetensi pedagogik melalui kegiatan Program Pengalaman Lapangan (PPL) dengan tujuan untuk memperoleh pengalaman dan wawasan sebagai persiapan menjadi calon guru yang cakap, percaya diri, dan terampil. Hal tersebut sejalan dengan pandangan Permatasari (2014) yang menjelasan bahwa kemampuan/keterampilan mengajar seorang calon guru diperoleh dari pengalaman-pengalaman dan wawasan mengajar baik dari teori maupun pengalaman praktis yang dapat memicu suatu kesuksesan dalam praktek mengajar

Sebagai calon guru, seorang mahasiswa PPL dituntut memiliki kompetensi pedagogik. Contohnya menguasai pembelajaran yang akan dibawakan, menguasai kelas, mampu menggunakan semua fasilitas yang disediakan serta memahami karakteristik setiap siswa. Kompetensi pedagogik seorang mahasiswa tidak diperoleh begitu saja, tetapi melalui mata kuliah khusus keterampilan mengajar yang diperoleh mahasiswa di kampus melalui dosen yang memiliki profesi dibidang pendidikan. Hal ini perlu dimiliki oleh mahasiswa agar proses pembelajaran dapat berjalan dengan baik. Pada kenyataannya masih banyak mahasiswa PPL yang kompetensi pedagogiknya belum memadai atau ada yang memadai tetapi belum dikatakan baik dikarenakan banyak siswa yang belum memahami apa yag diajarkan oleh mahasiswa PPL.

Berdasarkan wawancara yang dilakukan dengan guru di SMP Negeri 10 Kupang diketahui bahwa dalam kegiatan pembelajaran Biologi masih ditemukan banyak siswa yang tidak paham saat mahasiswa PPL membawakan materi pembelajaran. Kemudian ini berdampak terhadap hasil belajar siswa menjadi rendah, ada yang memuaskan tetapi hanya terbatas pada nilai KKM. Mahasiswa juga belum mampu mengelola pembelajaran dengan baik, belum mampu meyusun RPP dengan baik, belum mampu menggunakan teknologi yang tersedia dan kurang kreatif dalam meyiapkan alat peraga dalam proses pembelajaran. Akhirnya hanya beberapa siswa saja yang memperoleh nilai di atas rata-rata.Hal ini menunjukan bahwa kompetensi pedagogik mahasiswa PPL mununjukkan masih rendah, tetapi sejauh ini belum ada penelitian yang mengungkap bagaimana hubungan kemampuan pedagogik mahasiswa PPL dengan hasil belajar siswa di SMP Negeri 10 Kupang.

\section{METODE PENELITIAN}

\section{Lokasi dan Waktu Penelitian}

Penelitian dilaksanakan di SMP Negeri 10 Kupang pada semester genap tahun ajaran 2018/ 2019.

\section{Populasi dan sampel}

Populasi pada penelitian ini adalah siswa kelas VIII D SMP Negeri 10 kota kupang dan mahasiswa PPL program studi pendidikan biologi. Sampel dalam penelitian ini yaitu siswa kelas VIII yang berjumlah 21 orang dan mahasiswa PPL yang berjumlah 1 orang.

\section{MetodePenelitian}

Metode penelitian yang digunakan dalam penelitian ini yaitu penelitian korelasi dengan desain Korelasi Produc Momen

\section{Variabel Penelitian}

Variabel dalam penelitian Ini adalah variabel $X$ : kompetensi pedagogic mahasiswa PPL dan variabel $\mathrm{Y}$ adalah hasil belajar siswa 


\section{Desain Penelitian}

$$
r x y=\frac{\mathrm{N} \sum \mathrm{XY}-\left(\sum \mathrm{X}\right)\left(\sum \mathrm{Y}\right)}{\left.\sqrt{\left\{\mathrm{N} \sum \mathrm{X}^{2}-\left(\sum \mathrm{X}\right)^{2}\right\}\left\{\mathrm{N} \sum \mathrm{Y}^{2}\right.}-\left(\sum \mathrm{Y}\right)^{2}\right\}}
$$

Keterangan:

Gambar 1 Rumus Korelasi Product Momen

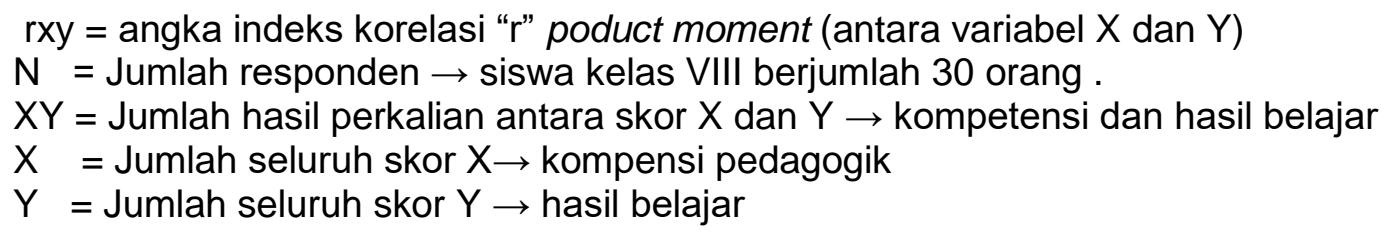

\section{Prosedur Penelitian}

1. Tahapan Persiapan meliputi: pembuatan kuisioner untuk kompetensi pedagogik dan instrument tes untuk mendapatkan data hasil belajar

2. Tahapan pelaksanaan: kuisioner untuk kompetensi pedagogik diberikan kepada mahasiswa PPL untuk di isi. Dan instrument tes akan diberikankepada siswa setelah mahasiwa PPL melaksanakan pembelajaran

3. Tahap pengumpulan data: Quisioner yang telah diisi dan hasil belajar siswa dikumpulkan kembali untuk dilanjutkan pada tahap analisis.

4. Tahapan Pengolahan data meliputi: uji normalitas, uji hipotesis penelitian, dan penarikan kesimpulan.

\section{Teknik pengumpulan Data}

Teknik pengumpulan data yang digunakan dalam penelitian ini yaitu tes hasil belajar dan angket. Tes digunakan untuk mengetahui sejauh mana penguasaan konsep siswa terhadap materi pelajaran setelah mengikuti proses belajar sedangkan angket diberikan kepada siswa untuk mengukur kompetensi pedagogic mahasiswa PPL.

\section{Teknik Analisis Data}

Teknik analisis data yang digunakan dalam penelitian ini yaitu dengan uji korelasi dengan bantuan program komputer SPSS versi 18. Uji korelasi digunakan untuk melihat hubungan antara kompetensi pedagogik dan hasil belajar. 
Data hasil penelitian menunjukkan kompetensi pedagogik mahasiswa PPL bahwa Gambar 2.

Keterangan :

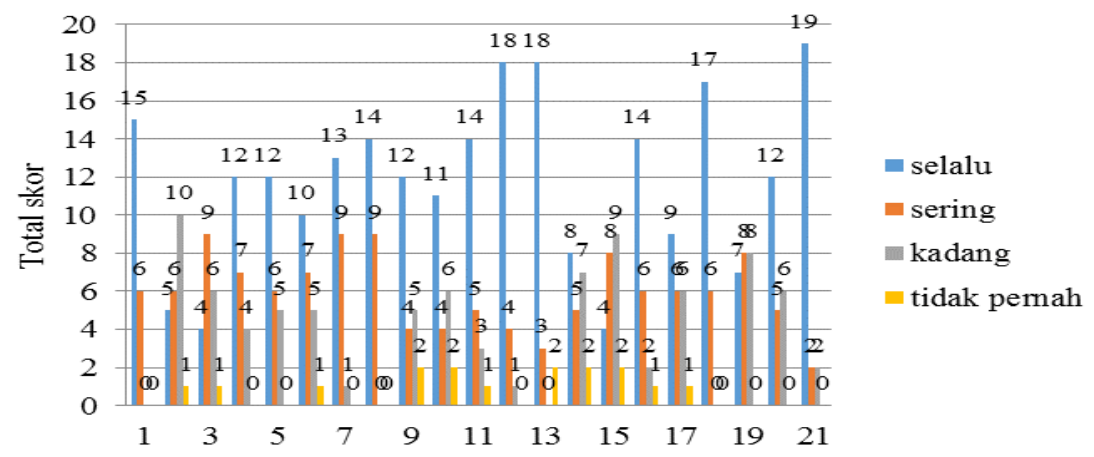

Gambar 2. Grafik Nilai angket kompetensi pedagogik

sumbu $x$ : responden;

sumbu y : total skor

Berdasarkan data pada Gambar 2 menunjukan bahwa setiap siswa memiliki penilaian yang berbeda, jawaban yang paling sering dipilih oleh responden adalah jawaban selalu dan paling jarang dipilih adalah jawaban tidak pernah, grafik juga menjelaskan bahwa jawaban selalu memiliki kriteria penilaian tertinggi yaitu skor 19 yang di diperoleh dari responden nomor 21 dan skor terendah adalah jawaban tidak pernah dengan skor masing-masing item jawaban hanya di atas 1.

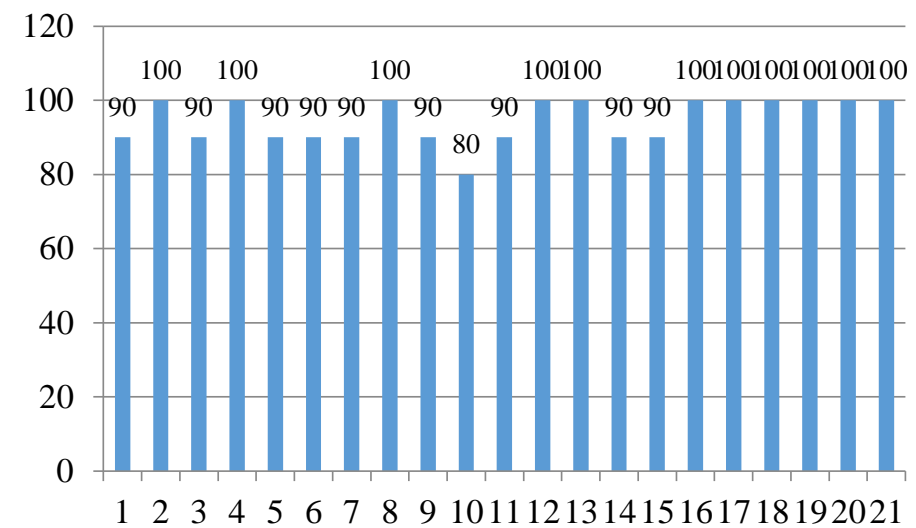

Gambar 3. Grafik Nilai hasil belajar

Keterangan sumbu $\mathrm{x}$ : responden, sumbu $\mathrm{y}$ : total skor

Dari grafik di atas dapat diketahui bahwa yang memperoleh nilai 100 berjumlah 11 orang, yang memperoleh nilai 80 berjumlah 1 orang, dan yang lainnya mendapatkan nilai rata-rata 80 90 .

\section{Hasil Uji Korelasi}

Uji korelasi digunakan untuk mengetahui Hubungan antara kompetensi pedagogik mahasiswa PPL dan hasil belajar siswa Hasil uji korelasi dapat dilihat pada Tabel1. sebelum dilakukan uji korelasi dilakukan uji linearitas dan uji normalitas sebagai prasyarat uji korelasi. Berdasarkan uji normalitas data menunjukkan kedua variabel berdistribusi normal dengan taraf signifikan kompetensi pedagogic mahasiswa PPL adalah 0,954 >0,05 dan hasil belajar siswa 
$0,120>0,05$. Selanjutnya Berdasarkan uji linearitas menunjukkan nilai signifikan 0,506 >0,05 yang artinya variabel kompetensi pedagogik mahasiswa PPL dan hasil belajar siswa memeililiki hubugan yang linear. Maka dapat dilanjutkan pada analisis korelasi pada Tabel 1.

Tabel 1 Hasil Uji korelasi Korelasi

\begin{tabular}{llll}
\hline & & $\begin{array}{l}\text { Kompetensi } \\
\text { pedagogik }\end{array}$ & $\begin{array}{c}\text { Hasil } \\
\text { belajar }\end{array}$ \\
\hline Kompetensi & Korelasi Pearson & 1 &,- 359 \\
\cline { 2 - 4 } pedagogic & Sig. (2-tailed) & &, 110 \\
Mahasiswa & $\mathrm{N}$ & 21 & 21 \\
\hline Hasil belajar & Korelasi Pearson &,- 359 & 1 \\
siswa & Sig. (2-tailed) &, 110 & \\
\cline { 2 - 4 } & $\mathrm{N}$ & 21 & 21 \\
\hline
\end{tabular}

Pada Tabel uji korelasi diperoleh nilai $\mathrm{R}$ hitung 0,359 dengan taraf sig 0,110 , apabila taraf sig Alpha ditetapkan 0,05 maka nilai sig $(0,110>0,05)$ sehingga Ho diterima dan Ha ditolak artinya tidak terdapat hubungan antara kompetensi pedagogik mahasiswa PPL dengan hasil belajar siswa. Jika nilai korelasi dibandingkan dengan interpretasi koefesien product moment nilai $r$ hitung berada pada kisaran 0,200-0,400 yang artinya hubungan antara kedua variable yaitu kompetensi pedagogic mahasiswa PPL dan hasil belajar siswa berada pada kategori lemah atau/rendah. Untuk mengetahui seberapa besar sumbangan variabel $\mathrm{x}$ terhadap variabel $\mathrm{y}$, maka nilai pearson corelation dikuadratkan $\left(\mathrm{r}^{2}\right)$, dimana nilai pada penelitian ini diperoleh $\mathrm{r}$ sebesar $0,359^{2} \times 100 \%=12 \%$. Hal ini berarti sumbangan kompetensi pedagogik Mahasiswa PPL SMP Negeri 10 Kota Kupang terhadap hasil belajar sebesar 12\% dan sisanya 88\% disumbangkan oleh variabel lain yang tidak diteliti pada penelitian ini.

\section{PEMBAHASAN}

Skor kompetensi pedagogik mahasiswa PPL diperoleh dari angket yang diberikan pada siswa. Angket kompetensi pedagogik berisi 23 pertanyaan dengan pilihan jawaban selalu yang artinya mahasiswa PPL selalu memiliki kompetensi yang baik, jawaban sering yang artinya mahasiswa memiliki kompetensi pedagogik yang lumayan baik, jawaban kadang-kadang yang artinya kompetensi pedagogik cukup baik atau jawaban tidak pernah yang artinya kompetensi pedagogik mahasiswa kurang sama sekali.

Berdasarkan angket yang diberikan kepada siswa diketahui bahwa yang paling banyak dipilih siswa adalah jawaban selalu dengan total 248, jawaban sering 125 , jawaban kadang 86 , dan jawaban tidak pernah 16. Data kompetensi pedagogik ini menunjukan bahwa tidak semua kompetensi dimiliki oleh mahasiswa PPL yang artinya mahasiswa PPL belum memiliki kompetensi pedagogic yang baik. sedangkan hasil belajar siswa berbanding terbalik dengan kompetensi pedagogik. Siswa memperoleh hasil belajar yang sangat memuaskan yaitu nilai tertinggi adalah 100 dan terendah 80, melihat data tersebut dapat diartikan bahwa minimnya kompetensi pedagogik mahasiswa PPL tidak berpengaruh secara langsung pada hasil belajar siswa.

Hal ini dibuktikan lagi dengan hasil pengujian hipotesis dimana diperoleh kompetensi pedagogik mahasiswa PPL dengan nilai sig 0,110>0,05 dan hasil belajar 0,110>0,05 artinya bahwa tidak ada hubungan yang signifikan antara kompetensi pedagogik mahasiswa PPL dengan hasil belajar siswa disekolah. Besarnya hubungan antara kompetensi pedagogik mahasiswa PPL dengan hasil belajar siswa disekolah berada pada kategori rendah/lemah yang ditunjukkan dari Besarnya nilai "r" Product moment yaitu -,359. besar sumbangan variabel kompetensi pedagogik mahasiswa PPL terhadap variabel hasil belajar mahasiswa sebesar $0,359^{2} \times 100 \%=12 \%$. Hal ini berarti sumbangan kompetensi pedagogik Mahasiswa PPL SMP Negeri 10 Kota Kupang dengan hasil belajar sebesar 12\% dan sisanya $88 \%$ disumbangkan dari variabael lain yang tidak dapat diteliti. 
Melihat bahwa sumbangan komptensi pedagogic mahasiswa PPL tergolong rendah dan hasil belajar yang diperoleh siswa setelah mengikuti pembelajaran sangat tinggi, hal ini dapat dipengaruhi oleh kemampuan dasar siswa dalam belajar sudah cukup baik, perhatian siswa dalam pebeljaran, minat belajar siswa sudah cukup baik, bakatdan kesiapan belajar siswa sudah cukup baik. Sebagaimana yang disampaikan Slameto (2010) bahwa prestasi/hasil belajar siswa dapat dipengaruhi oleh faktor-faktor antara lain: Faktor jasmaniah (kesehatan), Faktor psikologis, Perhatian, Minat, Bakat, Motif, Kematangan, dan kesiapan belajar.

Hal ini menunjukan bahwa kompetensi yang buruk, tidak selalu berdampak negatif terhadap hasil belajar siswa, dan kompetensi yang baik tidak selalu berdampak positif terhadap hasil belajar siswa karena pembelejaran yang optimal tergantung dari siswa itu sendiri, dan guru bukanlah satu-satunya sumber belajar, dan dapat mempergunakan apapun sumber/media untuk belajar (Oka, 2010). Selama penelitian mahasiswa PPL kurang menguasai beberapa kompetensi Pedagogik, kompetensi pedagogik terdiri dari delapan indikator, berdasarkan penelitian yang dilakukan indikator tertinggi yang dicapai oleh mahasiswa PPL adalah perancangan pembelajaran, pelaksanaan pembelajaran yang mendidik dan dialogis, mengembangkan kurikulum dan silabus sedangkan indikator yang cukup dikuasai oleh mahasiswa PPL adalah kemampuan mengelola pembelajaran, pemahaman peserta didik, pemanfaatan teknologi pembelajaran, evaluasi pembelajaran, selama penelitian mahasiswa PPL lebih banyak berbicara dan siswa mendengarkan, ijin keluar berulang kali dan diabaikan oleh mahasiswa PPL, tidak ada penggunaan carta/poster/alat peraga dan LCD dalam proses pembelajaran sehingga pembelajaran terkesan membosankan, beberapa siswa mengejek teman satu sama lain walaupun mahasiswa PPL berada didepan kelas sehingga kelas terkesan tidak kondusif.

Dalam penelitian langka awal yang digunakan peneliti adalah menyapa siswa, menjelaskan pada siswa apa yang dimaksud dengan angket, angket adalah suatu daftar atau kumpulan pertanyaan tertulis yang harus dijawab dengan tertulis juga Winkel (1987), langkah selanjutnya adalah memberikan tes, tes dilakukan pada hari yang berbeda, tes merupakan alat ukur yang dibuat dalam bentuk tugas-tugas individu yang telah distandarisasi yang kemudian diberikan pada individu atau kelompok tertentu untuk dikerjakan atau direspon (Matondang, 2009).

Penelitian ini mempunyai fakta bahwa baik atau tidaknya kompetensi pedagogik mahasiswa PPL tidak ada korelasinya dengan hasil belajar siswa. Hal ini terjadi bahwa disaat mahasiswa PPL menguasai kompetensi pedagogik tetapi siswa sedang tidak tertarik untuk belajar maka hasilnya juga kurang optimal, sebaliknya apabila mahasiswa PPL tidak memiliki penguasaan kompetensi pedagogik tetapi siswa memiliki minat belajar yang baik maka hasilnya akan optimal. Mahasiswa PPL diharapkan memiliki kompetensi pedagogik yang baik dan mampu. Selain itu kompetensi pedagogic juga dapat diimplementasikan dengan baik jika tersedia sarana dan prasarana yang mendukung (Rasuli dkk., 2013). Dalam mengimplementasikan delapan indikator pedagogik guru dalam proses belajar mengajar. Penelitian ini hanya dalam ruang lingkup kecil, artinya hanya megukur bagaimana hubungan kompetensi pedagogik dengan hasil belajar siswa.

\section{KESIMPULAN}

Dari hasil penelitian dan pembahasan yang telah dikemukakan maka dapat ditarik kesimpulan bahwa tingkat hubungan kompetensi pedagogik dan hasil belajar siswa kelas di SMP Negeri 10 Kupang memiliki korelasi yang rendah /lemah. Kompetensi pedagogic yang baik ataupun kurang dari guru bukan satu-satunya yang menentukan hasil belajar siswa, hal ini disebabkan karena adanya faktor internal yang turut berpengaruh meliputi minat, kesehatan, intelegensi, dan motivasi dari siswa untuk belajar, kesiapan belajar. Jika kompetensi pedagogik seorang mahasiswa baik tetapi siswa pada saat itu tidak memiliki keinginan / ketertarikan terhadap materi tersebut maka hasil belajar yang optimal tidak akan tercapai, sebaliknya jika kompetensi pedagogik mahasiswa kurang tetapi minat dan ketertarikan siswa terhadap materi tersebut baik maka hasil belajar yang optimal akan tercapai, tetapi sebagai seorang guru sudah 
selayaknya memiliki kompetensi pedagogik yang baik agar dapat menguasai situasi/kondisi dalam proses pembelajaran.

\section{DAFTAR PUSTAKA}

Annisa, (2005) Persepsi Siswa Tentang Kompetensi Proefesional Guru Matematika dengan Motivasi Belajar Matematika Pada Siswa Kelas VII SMA Negeri Medan.

Arikunto, S. (2009). Dasar-Dasar Evaluasi Pendidikan. Jakarta: Bina Aksara.

Arsyad, A. (2011). Media Pembelajaran. Jakarta: Raja Grafindo Persada.

Covey, S. R. (1997). Principle Centered Leadership. Jakarta: Bina Rupa Aksara.

Depdiknas. (2005). Undang-Undang Republik Indonesia Nomor 14 Tahun 2005 Tentang Guru dan Dosen. Jakarta: Depdiknas.

Hamalik, O. (2003). Pendidikan Guru Berdasarkan Pendekatan Kompetensi Jakarta: Bumi Aksara.

Hamalik, O. (2008). Kurikulum dan Pembelajaran. Jakarta: Bumi Aksara.

Hamalik, O. (2011). Proses Belajar Mengajar. Jakarta: Bumi Aksara.

Hasibuan, J. J., \& Moedjiono (2012). Proses Belajar Mengajar. Bandung: Remaja Rosdakarya.

Irawan, P. (2007). Hubungan Persepsi terhadap Kompetensi Guru dengan Motivasi Berprestasi Siswa Kelas VII SMP Negeri 2 Tirto. Skripsi Fakultas Psikologi, Universitas Diponegoro, Semarang.

Kusuma, W. (2015) Pengaruh Kompetensi Pedagogik Guru Kompetensi Profesional Guru dan Lingkungan Belajar Terhadap Motivasi Belajar Siswa Kelas XI Jurusan Administrasi Pekontrakan SMK Wijaya Jatilawang

Matondang, Z. (2009). Validitas dan Reliabilitas Suatu Instrumen Penelitian. Jurnal Tabularasa, 6(1), 87-97.

Mulyasa, E. (2008). Uji Kompetensi dan Penilaian Guru. Bandung: Remaja Rosdakarya.

Mulyasa, E. (2009). Standar Kompetensi dan Sertifikasi Guru. Bandung: Remaja Rosadakarya.

Oka, A. A. (2010). Pengaruh Penerapan Belajar Mandiri Pada Materi Ekosistem terhadap Keterampilan Berpikir Kritis dan Kemampuan Memecahkan Masalah Siswa SMA di Kota Metro. Bioedukasi: Jurnal Pendidikan Biologi, 1(2), 1-9. DOI: http://dx.doi.org/10.24127/bioedukasi.v1i2.191

Panitia Pelaksana PPL. (2018). Panduan Pelaksanaan Praktik Lapangan Fakultas Keguruan dan IImu Pendidikan. Kupang. Universitas Kristen Artha Wacana.

Permatasari, W. W. (2014) Hubungan Pengalaman Pembelajaran Microteaching Dengan Program Pengalaman Lapangan (PPL) Mahasiswa Pendidikan Akuntansi Universitas 
Muhammadiyah Surakarta (UMS) Angkatan 2010. Skripsi thesis, Universitas Muhammadiyah Surakarta.

Permendikbud Nomor 16 Tahun 2007 tentang Standar Kualifikasi Akademik dan Kompetensi Guru. Jakarta: Mendikbud.

Purwanto. (2010). Evaluasi Hasil Belajar. Yogyakarta: Pustaka Pelajar.

Ramayulis. (2002). Metodologi Pendidikan Agama Islam. Jakarta: Kalam Mulia.

Rasuli, A., Rivaie, W., \& Sulistyarini. 2013. Kompetensi Pedagogik Guru Dalam Meningkatkan Hasil Belajar Siswa Mata Pelajaran Sosiologi. Jurnal Pendidikan dan Pembelajaran Khatulistiwa : 2 (4).

Rifa'i, A., \& Anni, C. T. (2009). Psikologi Pendidikan. Semarang: Universitas Negeri Semarang Press.

Rustaman, N. Y. (2011). Pendidikan dan Penelitian Sains dalam Mengembangkan Keterampilan Berpikir Tingkat untuk Pembangunan Karakter. Prosiding Seminar Nasional VIII Pendidikan Biologi Vol. 8, No. 1. Universitas Sebelas Maret, Surakarta.

Santrok, J. W. (2007). Psikologi Pendidikan. Jakarta: Kencana Prenada Media Group.

Slameto, (2010). Belajar dan faktor-faktor yang Mempengaruhinya. Jakarta: Rineka Cipta.

Susanto, A. (2013). Teori Belajar dan Pembelajaran di Sekolah Dasar. Jakarta: Kencana Prenada Media Group.

Syah, H. (2007). Metodologi Penelitian. Pekanbaru: UIN Sulthan Syarif Kasim.

Uno, H. B. (2008). Perencanaan Pembelajaran. Jakarta: Bumi Aksara.

Uno, H. B., \& Muhammad, N. (2012). Belajar dengan Pendekatan PAILKEM. Jakarta. Bumi Aksara.

Usman, M. U. (2005). Menjadi Guru Profesional. Bandung: Remaja Rosdakarya. Matondang, Z. (2009). Validitas dan Reliabilitas Suatu Instrumen Penelitian. Jurnal Tabularasa, 6(1), 8797.

Winkel, W.S. (1987). Psikologi Pengajaran. Jakarta: Gramedia

Abdurrahman, M. (2003). Pendidikan Bagi Anak Berkesulitan Belajar. Jakarta: Rineka Cipta. 